\title{
Incorporating Technological Innovation and Environmental Strategy: An Integrated View of Cognition and Action
}

\author{
Xuanwei Cao \\ Department of Management, Xi'an Jiaotong-Liverpool University, Suzhou,
}

China

\section{Introduction}

Research on (natural) environment issues in the filed of strategic management has a long history. Before the forming of RBV, scholar had put forwarded the natural resource-based firm theory, incorporated the challenges of natural environment issues into the scope of strategic management research (Hart, 1995). Considering the complex relationship between firms and natural environment, how to obtain sustainable competitive advantage under intensive competitive context with serious environmental and energy challenges and crisis is becoming an important issue with rising research concerns. Studies in existing literatures have explored widely on this issue, including strategic proactivity and approach to natural environment (Aragón-Correa, 1998; Sharma, 2000), the selection of corporate environment strategy (Sharma, 2000), proactive environment strategy and organizational competitiveness (Sharma \& Vredenburg, 1998; Aragón-Correa, 2003), factors impacting environment strategy (González-Benito \& González-Benito, 2006), organization and environment (Etzion, 2007), impact of institutions on corporate environment strategy (Wahba, 2010) as well as impact of environment strategy on organizational performance in varied contexts (Aragón-Correa et al, 2008). However, these studies followed still the routine of swings of a pendulum in traditional strategy management, i.e., the swing of research perspectives between "looking outside-in" and "looking inside-out" without touching the micro foundation of strategy formation (Hoskisson et al, 1998). As a positive response to the initiative of Gavetti (2005), this paper tries to explain the formation and development of corporate environment strategy through combining the perspectives of cognition and action.

A conceptual model would be put forwarded to explain different patterns of corporate environment strategy under varied configuration of managerial cognition and strategic action. Based on this conceptual model, this paper would shed light on the dynamic change and development of corporate environment strategy. We try to offer a new perspective and understanding to important questions on corporate environment strategy. To our minds, in coping with environment challenges in corporation, three questions should be understood and answered by managers. The first is 'what' question, what kinds of measures (such as management system, technological innovation, etc.) should be adopted to deal with 
environment issues in business? The second is 'how' question, how to take these actions? Take organizational learning as example, the 'how' question relates to the selection of corporation in taking actions, such as global search or local search. And the third is 'when' question, which involves the time and timing factor in taking actions. For example, managers should consider the selection and adoption of different strategies in making innovation, such as keeping in-sync with competitors or following competitors. Thus, corporate environment strategy would be studied as a time dependent process by holding a "looking inside-out" perspective focusing on the mechanism of the interaction between cognition and action. In turmoil and uncertain environment, organizations need to develop their capabilities on strategic learning and strategic innovation for winning sustainable competitive advantage. In this context, time must be considered as an important factor to help us understand how to converge managerial cognition into strategic action. This paper is expected to contribute to understand how variance of managerial cognition on time could cause different orientations of corporate environment strategy. It also offers an effort towards understanding of subjective aspect of time and the psychological foundation of the origin of strategy. The second section investigates different research perspectives and focus of previous research on environment strategy, finding out the research gap. The third section illustrates the micro foundation of the formation of environment strategy, exploring the dynamic relationship between managerial cognition and action, pointing out the importance of incorporating time dimension into consideration of environment strategy. The fourth section concludes and indicates more meaningful research in future as well as managerial implications.

\section{Corporate environment strategy}

Environment issue in corporations is increasingly a focus of analytical interest in the study of corporate strategy. In particular, the notion of 'environment strategy' has penetrated into the scope of strategic management and come to prominence as an important challenge in front of managers and students of strategy research. A number of scholars have identified ambiguities and unresolved questions associated with the concept. Until now, there is no universally accepted definition of environment strategy. According to Sharma (2000), it can be thought of as "the mode of managing the interface between business and natural environment, a series of action results from adopting measures voluntarily to reduce negative impacts on environment". This definition follows the traditional path of strategy research, understanding strategy as a series of actions, focusing on firm level. In response to the recent initial research advice on exploring the micro foundations of strategy, environment strategy is thought to comprise both cognition and action aspects of managers when dealing with environment issues in pursuing sustained competitive advantage in business operation. It is time dependent and context dependent (i.e., industries, scopes, ownerships, countries, governance, etc.).

To understand better the fuzzy concept of environment strategy in previous research, Table 1 below illustrates the different research questions, focus, analytical perspectives and conclusions summarized from previous research on this issue. Through this way, we are aiming to expose the 'dilemma of innovation' of managers in front of environment challenges in practice. 
Incorporating Technological Innovation and Environmental Strategy:

\begin{tabular}{|c|c|c|c|c|}
\hline Source & Research question & Focus & Perspective & Conclusion \\
\hline $\begin{array}{l}\text { Russo \& } \\
\text { Fouts } \\
(1997)\end{array}$ & $\begin{array}{l}\text { Associations between } \\
\text { environment } \\
\text { performance and economic } \\
\text { performance }\end{array}$ & $\begin{array}{l}\text { Organizational } \\
\text { performance }\end{array}$ & $\begin{array}{l}\text { Looking } \\
\text { inside }\end{array}$ & $\begin{array}{l}\text { Environment performance and } \\
\text { economic performance are } \\
\text { positive related, influenced } \\
\text { from industry growth }\end{array}$ \\
\hline $\begin{array}{l}\text { Aragón- } \\
\text { Correa } \\
(1998)\end{array}$ & $\begin{array}{l}\text { Relationship between } \\
\text { corporate strategy } \\
\text { proactivity and the attitude } \\
\text { of corporate on natural } \\
\text { environment }\end{array}$ & $\begin{array}{l}\text { Strategy } \\
\text { proactivity }\end{array}$ & $\begin{array}{l}\text { Looking } \\
\text { inside }\end{array}$ & $\begin{array}{l}\text { It is inter-related between } \\
\text { strategy proactivity and the } \\
\text { attitude of corporate on } \\
\text { natural environment }\end{array}$ \\
\hline $\begin{array}{l}\text { Sharma \& } \\
\text { Vredenburg } \\
\text { (1998) }\end{array}$ & $\begin{array}{l}\text { The role of Proactive } \\
\text { environment } \\
\text { strategy on organizational } \\
\text { capability } \\
\text { development }\end{array}$ & $\begin{array}{l}\text { Proactive } \\
\text { environment } \\
\text { strategy }\end{array}$ & $\begin{array}{l}\text { Looking } \\
\text { inside }\end{array}$ & $\begin{array}{l}\text { It is intensively inter-related } \\
\text { between corporations' positive } \\
\text { response to environment } \\
\text { issues and organizational } \\
\text { special capabilities (such as } \\
\text { sustained innovation, } \\
\text { integrating stakeholders, and } \\
\text { organizational learning) }\end{array}$ \\
\hline $\begin{array}{l}\text { Rhee \& Lee } \\
\text { (2003) }\end{array}$ & $\begin{array}{l}\text { Dynamic change of } \\
\text { corporate } \\
\text { environment strategy }\end{array}$ & $\begin{array}{l}\text { 'Ritual' and } \\
\text { 'real' of } \\
\text { corporate } \\
\text { environment } \\
\text { strategy }\end{array}$ & $\begin{array}{l}\text { Looking } \\
\text { inside }\end{array}$ & $\begin{array}{l}\text { Internal factors in } \\
\text { organizational play significant } \\
\text { role on influencing corporate } \\
\text { environment strategy }\end{array}$ \\
\hline $\begin{array}{l}\text { Aragón- } \\
\text { Correa } \\
\text { et al }(2008)\end{array}$ & SMEs' environment strategy & $\begin{array}{l}\text { SMEs' } \\
\text { environment } \\
\text { strategy and } \\
\text { economic } \\
\text { performance }\end{array}$ & $\begin{array}{l}\text { Looking } \\
\text { outside-in }\end{array}$ & $\begin{array}{l}\text { SMEs show varied patterns of } \\
\text { environment strategy. More } \\
\text { proactive environment } \\
\text { strategy can promote and } \\
\text { enhance organizational } \\
\text { performance }\end{array}$ \\
\hline $\begin{array}{l}\text { Fraj- } \\
\text { Andrés } \\
\text { et al (2009) }\end{array}$ & $\begin{array}{l}\text { Factors influencing } \\
\text { corporate } \\
\text { environment strategy }\end{array}$ & $\begin{array}{l}\text { corporate } \\
\text { environment } \\
\text { strategy in } \\
\text { Spanish } \\
\text { context }\end{array}$ & $\begin{array}{l}\text { Looking } \\
\text { outside-in }\end{array}$ & $\begin{array}{l}\text { Competitive dynamics and } \\
\text { management commitment are } \\
\text { important factors influencing } \\
\text { the incorporation of } \\
\text { environment issues into } \\
\text { corporate strategy }\end{array}$ \\
\hline $\begin{array}{l}\text { Wahba } \\
(2010)\end{array}$ & $\begin{array}{l}\text { Institutional shareholders' } \\
\text { control and influence on } \\
\text { corporate environment } \\
\text { strategy in different } \\
\text { institutional contexts }\end{array}$ & $\begin{array}{l}\text { Institutional } \\
\text { shareholders }\end{array}$ & $\begin{array}{l}\text { Looking } \\
\text { outside-in }\end{array}$ & $\begin{array}{l}\text { Different institutional } \\
\text { shareholders have } \\
\text { different impacts on } \\
\text { corporate environment } \\
\text { strategy }\end{array}$ \\
\hline $\begin{array}{l}\text { Buysse \& } \\
\text { Verbeke } \\
(2003)\end{array}$ & $\begin{array}{l}\text { Correlativity between } \\
\text { corporate } \\
\text { environment strategy } \\
\text { and the management of } \\
\text { stakeholders }\end{array}$ & stakeholders & $\begin{array}{l}\text { Looking } \\
\text { inside-out }\end{array}$ & $\begin{array}{l}\text { The correlation between } \\
\text { corporate environment } \\
\text { strategy and stakeholders } \\
\text { management is } \\
\text { influenced from other } \\
\text { external factors }\end{array}$ \\
\hline $\begin{array}{l}\text { Banerjee } \\
(2001)\end{array}$ & $\begin{array}{l}\text { Influence from managerial } \\
\text { perception on environment- } \\
\text { orientation and } \\
\text { environment strategy }\end{array}$ & $\begin{array}{l}\text { managerial } \\
\text { perception }\end{array}$ & $\begin{array}{l}\text { Looking } \\
\text { inside-out }\end{array}$ & $\begin{array}{l}\text { Perceptions towards } \\
\text { regulations, public } \\
\text { environment awareness, top- } \\
\text { level managerial commitment } \\
\text { and achievement of } \\
\text { competitive advantage could } \\
\text { be transferred into corporate } \\
\text { environment strategy }\end{array}$ \\
\hline
\end{tabular}




\begin{tabular}{|c|c|c|c|c|}
\hline Source & Research question & Focus & Perspective & Conclusion \\
\hline $\begin{array}{l}\text { Worthington } \\
\text { \& Patton } \\
(2005)\end{array}$ & $\begin{array}{l}\text { To what extent is corporate } \\
\text { green environment } \\
\text { management influenced } \\
\text { by manager's strategic } \\
\text { intention }\end{array}$ & $\begin{array}{l}\text { strategic } \\
\text { intention }\end{array}$ & $\begin{array}{l}\text { Looking } \\
\text { inside-out }\end{array}$ & $\begin{array}{l}\text { Managers in SMEs lack } \\
\text { strategic intention to make } \\
\text { environment performance a } \\
\text { source of competitive } \\
\text { advantage }\end{array}$ \\
\hline $\begin{array}{l}\text { Sharma } \\
(2000)\end{array}$ & $\begin{array}{l}\text { Influence of managerial } \\
\text { interpretation in } \\
\text { specific context on } \\
\text { corporate } \\
\text { environment strategy }\end{array}$ & $\begin{array}{l}\text { managerial } \\
\text { interpretation }\end{array}$ & $\begin{array}{l}\text { Looking } \\
\text { inside-out \& } \\
\text { Looking } \\
\text { outside-in }\end{array}$ & $\begin{array}{l}\text { Managerial interpretation to } \\
\text { environmental } \\
\text { issues is influenced by } \\
\text { contextual factors }\end{array}$ \\
\hline $\begin{array}{l}\text { Sharma, } \\
\text { Pablo \& } \\
\text { Vredenburg } \\
(1999)\end{array}$ & $\begin{array}{l}\text { Association between } \\
\text { managerial } \\
\text { interpretation to } \\
\text { environment issues and } \\
\text { subsequent responses } \\
\text { adopted }\end{array}$ & $\begin{array}{l}\text { Internal and } \\
\text { external } \\
\text { factors } \\
\text { influencing } \\
\text { corporate } \\
\text { environment } \\
\text { response } \\
\text { strategy }\end{array}$ & $\begin{array}{l}\text { Looking } \\
\text { inside-out \& } \\
\text { Looking } \\
\text { outside-in }\end{array}$ & $\begin{array}{l}\text { Managerial interpretation to } \\
\text { environment issues (such as } \\
\text { opportunity or threat; } \\
\text { controllable or uncontrollable; } \\
\text { benefits or losts) decide } \\
\text { corporations' responses }\end{array}$ \\
\hline
\end{tabular}

Table 1. Research on Environment Strategy

Through a systematic literature review, the previous research on environment strategy could be divided to three categories. The first group studies concern about the antecedents of environment strategy; the research question concerned is what factors can influence the formation of corporate environment strategy. The second group studies concern about the ex post outcomes of corporate environment strategy, i.e., exploring the impact of corporate environment strategy on economic and environmental performance of organizations, as well as the causal relationship between those antecedent factors and ex post outcomes. The third group studies try to find out the mechanism for the formation of environment strategy, i.e., exploring the micro foundation of environment strategy from cognition aspect. However, studies on exploring how cognition is transferred to strategic action and how environment strategy is constructed in organization are still lacking. Studies in the first group and the second group try to link directly the causal chain between the antecedent factors influencing environment strategy and the ex post outcomes from environment strategy, ignoring yet the micro foundation of the formation of environment strategy. Figure 1 below illustrates the antecedents and ex post outcomes as well as the inner black box of the formation of environment strategy.

As illustrated in Figure 1, antecedent factors influencing environment strategy include stakeholders, institution environment, firm, and competitors. Many studies before have made analysis at industry level, exploring how different ownership and firm scope, different industries, different institution environment, and different governance structure influence corporate environment strategy. This research tradition focuses actually the force of external factors on organization, reflecting a research perspective of 'looking outside-in' and an epistemology of environment determinism. It holds a relative static perspective without touching the 'black box' of strategy. Recently, some scholars have advocated considering the impact of dynamic competition on organization strategic actions. In dynamic competition, varied environment performance from different environment strategy is influenced from corporation's response to competitor's actions. 


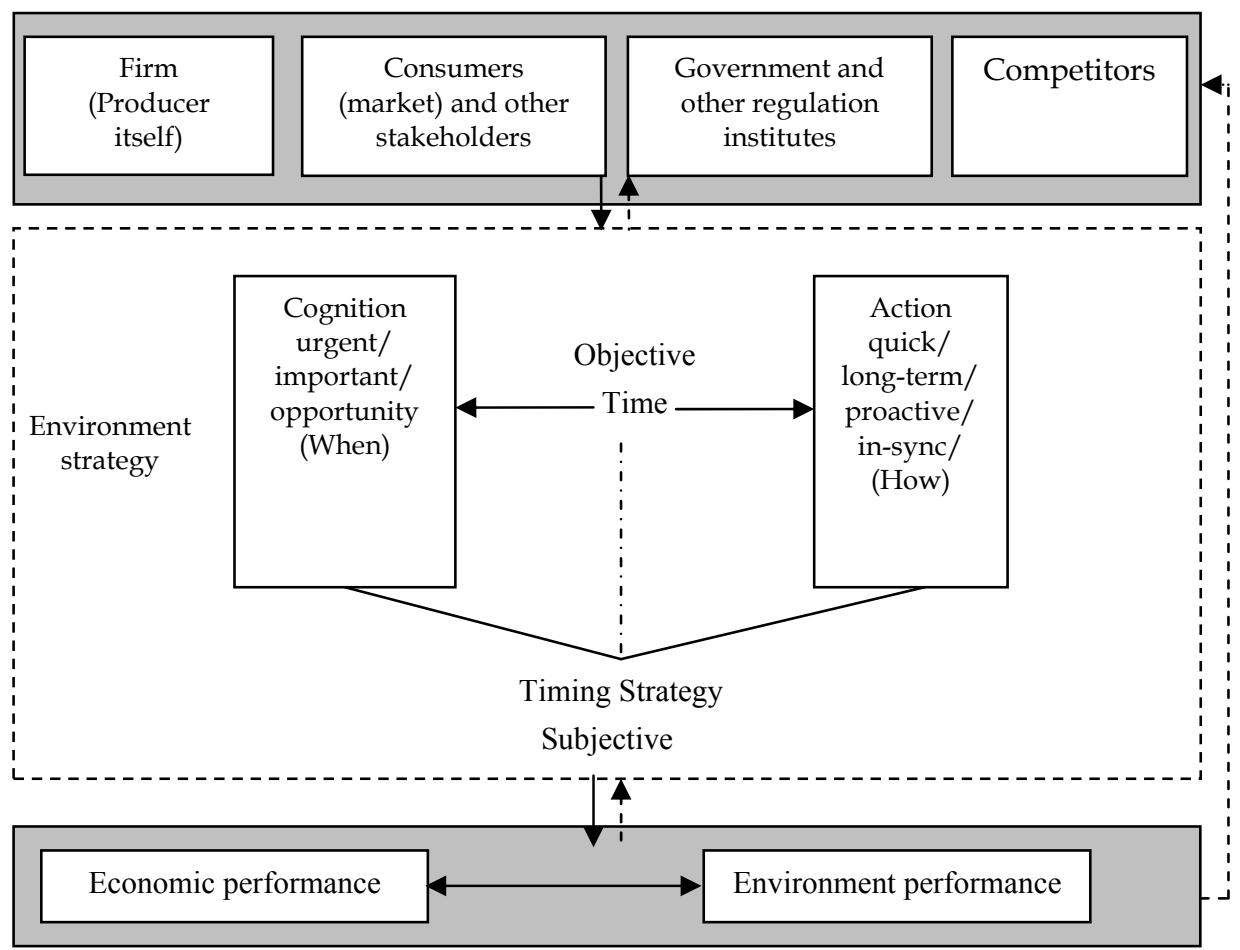

Fig. 1. The Antecedence and Outcome of Environmental Technological Strategy

With deepening research on the origin of strategy, scholars put forward to combine both 'looking outside-in' and 'looking inside-out' perspectives to explore how cognition and action at individual level impact strategy and dynamic capability at organization level.

In this paper, we make a try to explore how managerial cognition and action at individual level could impact the formation, implementation, renewal and innovation of corporate environment strategy at organization level.

\section{A micro perspective on corporate environment strategy}

\subsection{Micro foundation of strategy}

In recent years, studies on organizational performance, dynamic capabilities and strategy are presenting strong interest on exploring the micro foundation (Narayanan, Zane and Kemmerer, 2011). Attentions in studies on strategy has been experiencing the shift from concerning "strategic contents" to "strategic process" and "strategy-in-practice", focusing more intensively on answering the 'how' question, i.e., how does the formation, implementation and renewal (innovation) of strategy happen? At the same time, in turbulent times, the uncertainty of managers and their actions to ambiguous issues are impacting organizational strategy and performance prominently. The recent initiatives on 
calling for more investigations on the micro foundation for the formation of strategy open a new avenue to understand the strategy in practice (Lovallo et al, 2008; Jaworski, Balogun, and Seidl, 2007). Eisenhardt et al (2010) put forwarded that more research in strategy and organization should be taken to explore the micro foundations of organizational performance under dynamic environmental conditions. This is consistent with the suggestion from Meindl (1994) that the most important research in future must establish the links among cognition, behavior and organizational performance.

When studies penetrate into the inner mechanisms of the changing of strategy process, the dual characters of strategy was excavated. In their study of the origin of strategy, Gavetti \& Rivkin (2007) pointed out that strategy is a unification of managerial cognition and action. On the one hand, strategy exists in the minds of managers, embodied as their perception towards the world and the position of their companies; on the other hand, strategy is represented as actions of companies, refined through specific activities, rules and routines. Since both cognition and action evolves over time, the strategic task for management is finally to keep an alignment between managerial cognition and action in dynamic changing situations. In this process, the managerial cognition framework and the interpretations to environment from managers compose the foundation for the actions of managers. Many studies have proven the relationship between managerial cognition and strategic action (Cho \& Hambrick, 2006; Kaplan, 2008). Following this emerging mode on bridging the link between individual's micro cognition and organization's macro action, recent studies examined also the impact of CEO's attention on organization's adoption of new technology (Eggers \& Kaplan, 2009). A noteworthy piece among those studies is the analysis conducted by Miller \& Chen (1994). They pointed out that managers often tend to do what they have done the best, causing a 'downward spiral' of organizational development, and leading to a path of organization recession.

Although previous research have disclosed the inter-relationship between managerial cognition and strategic action and the impact of managerial on organizational performance, they presented few dynamic descriptions on cognition, without illustrating how cognition changes under influences from external factors over time in dynamic environment and the subsequent impacts on organization. Recently, however, some scholars have noticed the problem and made efforts towards understanding the dynamic process of strategy. Nadkarni \& Barr(2008) tried to integrate studies on environment context, managerial cognition and strategic action to develop a more integrated and dynamic understanding of strategy process. McCarthy et al (2010) studied specifically the concept of environment velocity, considering in particular how environment velocity impacts strategic decisionmaking and new product development. These researches reflect the efforts of scholars to introduce dynamic perspective on understanding the change of cognition and the subsequent impact on actions at macro level. However, to a great extent the idea still follows a "looking outside-in" perspective, lacking stronger explanation power to the ultimate question of how cognition change over time.

In front of challenges from environment issues, a hard question for mangers in practice is to reckon when and how to conduct (environmental) technological innovation. Considering the dynamics of strategy, current research on organization and strategy is focusing on bridging 
the link between individual manager's cognition and organizational strategic actions as well as their interactions on organizational dynamic capabilities and organizational performance.

\subsection{Environment strategy through the lens of cognition and action}

Traditional study in the field of strategy tries to answer 'what' question (i.e., what is the right thing to do, what business to do) and 'how' question (i.e., how to take strategic actions to cope with external environment). The 'what' question pays attention to the contents of strategy, while the 'how' question concerns about the process of strategy. However, as environment is becoming more and more unstable and unpredictable, the traditional logic and perspective on strategy study could not offer effective solutions to give managers a clear guide on reckoning 'when' is suitable time (timing) to take strategic actions, such as a proactive environment strategy through technological innovation.

Because of the externality in making environment technological innovation, together with the imprinted perception of conflict and opposite between economic performance and environment performance, the problem of 'innovator's dilemma' is more prominent. For example, in coping with environment issues in business operation, managers in practice are always puzzled and confused by selecting a right way between radical innovation and incremental innovation, pursuing to be a technology leader or satisfying to be a technology follower, taking proactive actions or making response, creating a new path or sticking on path dependence. At the same time, these paradoxes are still hanging in doubt in academia. In front of these paradoxes, managers are far away from possessing the ambidexterity capability to solve such kind of ambiguous issue as environment strategy. What scholars observed of the variance of environment strategies in business could be tracked back actually to the variance of managerial cognition.

Sharma's study (2000) indicated that the selection of corporate environment strategy suffers from the impact of managerial cognition. Managers' interpretation of environment issues to be a threat or an opportunity influenced the selection of corporate environment strategy. Other studies considered also the influence of leadership styles on the environmental management (Bansal and Roth, 2000; Cordano and Frieze, 2000; Egri and Herman, 2000; Flannery and May, 2000; Sharma, 2000; Banerjee, 2001). Although this research tried to construct a link between individual behavior and organizational action, it didn't explore how contingent factors influenced managers' cognition and correspondent actions. Recently, studies on CEO's capability disclosed that the ambidexterity capability of decision-makers in dealing with ambiguous issues with both positive and negative meanings would decide the scope of action, risks and innovativeness (Plambeck \& Weber, 2009, 2010). Corporate environment strategy could be regarded as an ambiguous issue since there are still lots of enterprises that have not incorporated environment strategy as an important foundation for their organizations' sustained competitive advantage. Among many other factors influencing the orientation of corporate environment strategy, it is managerial cognition that impacts organization's reply to the 'when' and 'how' questions. Research about the relationship between short-term performance and longterm survival of organizations has pointed out that this relationship is partly decided by actions the organization adopted in response to external environment; and organizational actions are also partly impacted by the purposive behaviors of individuals especially 
decision-makers at higher level in organization (Dutton \& Jackson, 1987). Therefore, the study of organization strategy, in particular under ambiguity and uncertainty situations, must integrate individual actor's cognition to organization and environment with strategic actions at organizational level.

In their article, Buysse \& Verbeke (2003) divided three types of environment strategy, namely reactive strategy, pollution prevention strategy, and environment leadership strategy. We would develop further a typology of environment strategy according to managers' cognition on environment issues and the actions they adopted. Figure 2 shows the four different types of actors and their correspondent environment strategies.

\begin{tabular}{|l|l|}
\hline $\begin{array}{l}\text { Analyzer (Speculator) } \\
\text { (calculating the costs of taking } \\
\text { different strategic actions) }\end{array}$ & $\begin{array}{l}\text { Cognition } \\
\text { Pioneer (Green leader) } \\
\text { (turning green to gold) }\end{array}$ \\
$\begin{array}{l}\text { Wait and see } \\
\text { Reactor } \\
\text { (tending to take reactive measures } \\
\text { to smoothing challenges on } \\
\text { environmental issues) }\end{array}$ & $\begin{array}{l}\text { Follower } \\
\text { (fools rush-in in the green } \\
\text { wave, tracing pioneers' pace) }\end{array}$ \\
(3) & \multicolumn{1}{|c}{ Rush-in } \\
\hline
\end{tabular}

Fig. 2. A Typology of Environment Strategy Based on Cognition and Action

\section{Time dependence of environment strategy}

Strategy itself is time dependent (Eisenhardt, 2002). Considering the importance of environment issues on organization sustainable competitiveness, the formation, implementation and renewal of environment strategy could be varied on time-orientation. Due to different managerial perceptions towards organizational internal resources, organizational capabilities and development as well as pressures from external competitive environment and institution environment, corporate environment strategy in practice is actually embedded in a specific time frame which could be represented varied in terms of urgency vs. indifference, long-termism vs. short-termism, etc on cognitive aspect and proactivity vs. reactivity, path creation vs. path dependence, etc on action aspect. In uncertain and turmoil environment, it is harder and harder to pursue sustainable competitive advantage due to fast-paced competitive actions and counter responses among rivals. The requirement for more flexible strategy and strategic innovation raise an 
important issue for strategy study. That is how firms transition from one advantage to the next. When should they begin these transitions? How should managers manage time?

It is only in recent years that research on strategy management is becoming to make an echo to the initiative of Ancona et al (2001)'s research to make time a new research lens. Through the temporal lens, individual's time urgency and time perspective could be observed and integrated into a more holistic understanding of strategy, to achieve an ideal status of strategy management by doing right things right at right time. It is worthy to note that our understanding on the origin of strategy under the lens of an integrative perspective of cognition and action must be developed further with more consideration of the dynamic change of strategy. For example, the behavior of rivals' impacts on actor's cognition and action should be considered. In particular, the temporary component of competitive advantage, such as time pacing, sequence, frequency, time-orientation, etc., must be considered when making, implementing, renewing strategies in hypercompetition. The recent study of Katila \& Chen (2008) pointed out that it is actually search timing compared to competitors instead of competition that cause difference of innovation among organizations. In terms of the search timing, Katila \& Chen (2008) showed three strategies for organizations. The first is to keep ahead of competitors, exploring new field; the second is to keep in-sync with competitors, competing with rivals to provide new products to markets; the third is to keep following competitors, aiming to catch-up competitors in later time. This valuable research introduced a dynamic perspective towards understanding of strategic actions under varied contexts; however, we are still lacking knowledge on how cognition is transferred to strategic action in organization.

Nadkarni \& Barr(2008) made a try to explain the dynamic interactions between managerial cognition and strategic action through the moderating variable of speed of industry change. This opens a new path to bridge the link between managerial cognition and strategic action through the factor of time. Time is a variable with diversified meanings. In previous research, too often time is portrayed and interpreted based on the measured, linear, forward-moving, and exact clock time. In fact, time could also be reflected as the subjective experience of individual actors. Therefore, future exploration on manager's time cognition and its impact on strategic actions and structure of organization could help open the black box of strategy process and strategy in practice.

Considering the ambiguity and complexity of corporate environment strategy in the minds of managers in practice, we suppose this issue has different time frame in managers. According to the behavior theory of the firm, organization is a problem-solving entity with limited attentional capability (Cyert \& March, 1963). Compared to other issues with more directed influences on economic performance of organization, normally environment issues are allocated with less attention from managers. However, due to increasing pressures from other external factors, including regulators, stakeholders, and competitors, environment issues are also interpreted varied to some extent by managers due to their different managerial cognition. Among which, time is an important factor differentiating managerial cognition and consequent actions. Based on the research analysis on how different time cognition influences the formation, implementation and renewal of corporate environment strategy, we propose the following. 
PROPOSITION 1: If a manager posses a smooth cognition on time, he tends to adopt a responsive corporate environment strategy.

PROPOSITION 2: If a manager posses an urgent cognition on time, he tends to adopt a proactive corporate environment strategy.

PROPOSITION 3: If a manager predicts rival's innovation activities on environment issues, his time cognition of urgency would be reinforced.

PROPOSITION 4: If a manager pays more attention on emerging new technologies, the firm tends to be future-oriented, with earlier adoption of innovative technologies and earlier timing of entry into new market.

The examination of managers' different cognition on time offers a good point to disentangle the interactions between managerial cognition and strategic actions as well as their influence on organizational strategy and organizational performance. This is consistent with the recent initiative from Lovallo et al (2008) to explore the psychological foundation of strategy management.

\section{Discussion and implications}

We try to offer a new perspective and understanding to important questions on corporate environment strategy. To our minds, in coping with environment challenges in corporation, three questions should be understood and answered by managers. The first is 'what' question, what kinds of measures (such as management system, technological innovation, etc.) should be adopted to deal with environment issues in business? The second is 'how' question, how to take these actions? Take organizational learning as example, the 'how' question relates to the selection mechanism in taking actions, such as global search or local search. And the third is 'when' question, which involves the time and timing factor in taking actions. For example, managers should consider the selection and adoption of different strategies in making innovation, such as keeping in-sync with competitors or following competitors. Thus, corporate environment strategy would be studied as a time dependent process by holding a "looking inside-out" perspective focusing on the mechanism of the interaction between cognition and action.

From the attention based view of the firm (Ocasio, 1997), managers would focus more on economic performance when shareholders put more attention on the pressure of performance evaluations in organization. In this context, more attention on economic performance could create short-termism of managers instead of trying to maintain an ambidextrous trade-off between economic and environmental performance. Therefore, in practice, we need to combine both "looking outside-in" and "looking inside-out" perspectives to consider the impact of external factors on managers' cognition and action as well as the impact of individual manager's cognition on organizational strategic orientation. For example, with deepening localization of Foreign Invested Enterprises (FIEs) in China, indigenous managers in localized FIEs tend to put more attention on improving economic performance while reducing input on corporate environment issues. In this process, managers' cognition on the urgency and importance of environment issues could impact their temporal orientation on making, implementing and renewing corporate environment 
strategy. Therefore, it is meaningful and valuable to investigate how contextual factors could influence manager's cognition and its consequent strategic actions in future studies.

An integrated analysis of corporate environment strategy from both cognition and action aspects could help understand the micro mechanism for the formation, implementation and renewal of strategy, indicating possible solutions for managers to break the 'innovator's dilemma'. The introduction of time dimension into the analysis of dynamic change of cognition could increase our understanding on the interactive relationship between managerial cognition and strategic actions. For example, we can investigate the causal relationship between managerial cognition and actions on environment strategy through examining the degree of urgency of manager's cognition on environment issues, the temporal orientation of manager towards environment issues, the timing of taking actions with consideration of rival's behavior.

In view of the emerging shift of strategy research to strategy as practice, a time-based perspective on analyzing strategic activities ignites actually further thinking and research on solving the dilemmas in managerial practices, such as the 'when' and 'how' questions for managers in front of the serious challenges of triple E crisis (i.e., economy, environment, energy). Until now, environment technological innovation is still regarded widely as a paradox both in theory and practice. The tensions between radical innovation vs. incremental innovation, exploration vs. exploitation, proactive vs. reactive, paradigm shift vs. technological trajectory, first-mover vs. catch-up, hidden actually managers' different cognition on time. With increasing uncertainty in environment as well as fast-pacing strategic change and business model innovation of competitors, a 'right' time strategy to guide innovation is without doubt more and more important in terms of its prominent value on improving organization's competitiveness.

In terms of the methodology to measure cognition, a popular method is to apply the content analysis method based on the materials of Letter to Shareholders (LTS). Compared with the interview method, it could avoid the subjective reconstruction with an ex post analysis, benefiting a longitudinal analysis. Considering the emerging development and interest on measuring cognition in other related disciplines, it is really helpful to strengthen and integrate other methods into the study, such as the latest collaborative research from organizational strategy and organizational cognitive neuroscience (Senior, Lee, and Butler, 2011). To our mind, a reasonable and effective measurement of managers' cognition on time is an interesting but arduous challenge for future research. To understand well the micro psychological foundation of strategy formation, we encourage scholars from varied fields including but not least to those from psychology, politics and behavior research to improve our understanding on the dynamic link between managers' cognition and actions at micro level and the evolution and renewal of corporations' environment strategy at macro level.

\section{Acknowledgement}

The author wishes to thank Dr. Hua Zhang for his valuable suggestions for the earlier versions of the manuscript. Financial support by the National Natural Science Foundation of China (NSFC) to the Youth Scholar Research Project (70902021) is gratefully acknowledged. This paper is part of the research outcomes of the research project (70902021). 


\section{References}

[1] Hart, S.L. A Natural-Resource-Based View of the Firm. The Academy of Management Review, 1995, 20(4): 986-1014.

[2] Aragón-Correa, J.A. Strategic Proactivity and Firm Approach to the Natural Environment. The Academy of Management Journal, 1998, 41(5): 556-567.

[3] Sharma, S. Managerial Interpretations and Organizational Context as Predictors of Corporate Choice of Environmental Strategy. The Academy of Management Journal, 2000, 43(4): 681-697.

[4] Sharma, S., Vredenburg, H. Proactive corporate environmental strategy and the development of competitively valuable organizational capabilities. Strategic Management Journal, 1998, 19(8):729-753.

[5] Aragón-Correa, J.A., Sharma, S. A Contingent Resource-Based View of Proactive Corporate Environmental Strategy. The Academy of Management Review, 2003, 28(1): 71-88.

[6] González-Benito, J., González-Benito, Ó. A review of determinant factors of environmental proactivity. Business Strategy and the Environment, 2006, 15(2):87102.

[7] Etzion, D. Research on Organizations and the Natural Environment, 1992-Present: A Review. Journal of Management, 2007, 33(4): 637-664.

[8] Wahba, H. How Do Institutional Shareholders Manipulate Corporate Environmental Strategy to Protect Their Values. Business Strategy and the Environment, Business Strategy \& Environment, 2010, 19(8): 495-511.

[9] Aragón-Correa, J.A, Hurtado-Torres, N., Sharma, S., Garcia-Morales, V.J. Environmental strategy and performance in small firms: A resource-based perspective. Journal of Environment Management, 2008, 86(1): 88-103.

[10] Hoskisson, R.E., Hitt, M.A., Wan, W.P., Yiu, D. Theory and research in strategic management: Swings of a pendulum[J]. Journal of Management, 1999, 25(3): 417456.

[11] Gavetti, G. Cognition and hierarchy: Rethinking the microfoundations of capabilities' development. Organization Science, 2005, 16(6): 599-617.

[12] Russo, M.V., Fouts, P.A. A Resource-Based Perspective on Corporate Environmental Performance and Profitability. Academy of Management Journal 1997, 40(3): 534559.

[13] Rhee, S.K., Lee, S.Y. Dynamic change of corporate environmental strategy: rhetoric and reality. Business Strategy and the Environment. 2003, 12(3), 175-190.

[14] Fraj-Andrés, E., Martínez-Salinas, E., Matute-Vallejo, J. Factors affecting corporate environmental strategy in Spanish industrial firms. 2009, 18, 500-514.

[15] Buysse, K., Verbeke, A. Proactive environmental strategies: a stakeholder management perspective. Strategic Management Journal, 2003, 24(5): 453-470.

[16] Banerjee, S.B. Managerial perceptions of corporate environmentalism: interpretations from industry and strategic implications for organizations. Journal of Management Studies, 2001, 38(4): 489-513.

[17] Worthington, I., Patton, D. Strategic intent in the management of the green environment within SMEs: An analysis of the UK screen-printing sector. Long Range Planning, 2005, 38(2): 197-212. 
[18] Sharma, S., Pablo, A.L., Vredenburg, H. Corporate Environmental Responsiveness Strategies: The Importance of Issue Interpretation and Organizational Context. Journal of Applied Behavioral Science, 1999, 35(1): 87-108.

[19] Narayanan, V.K., Zane L.J., Kemmerer, B. The Cognitive Perspective in Strategy: An Integrative Review. Journal of Management, 2011, 37(1): 307-351.

[20] Gavetti, G., Rivkin, J.W. On the Origin of Strategy: Action and Cognition over Time. Organization Science, 2007, 18(3): 420-439.

[21] Eisenhardt, K.M., Furr, N.R., Bingham, C.B. Microfoundations of Performance: Balancing Efficiency and Flexibility in Dynamic Environments. Organization Science, 2010, 21(6): 1263-1273.

[22] Laamanen, T., Wallin, J. Cognitive Dynamics of Capability Development Paths. Journal of Management Studies, 2009, 46(6): 950-981.

[23] Cockburn, I.M., Henderson, R.M. and Stern, S. 2000. Untangling the origins of competitive advantage. Strategic Management Journal, 21(10-11), 1123-1145.

[24] Meindl, J. R., Stubbart, C., \& Porac, J. F. 1994. Cognition within and between organizations: five key questions. Organization Science, 5(3): 289-293.

[25] Ginsberg, A., Venkatraman, N. 1995. Institutional Initiatives for Technological-Changefrom Issue Interpretation to Strategic Choice. Organization Studies, 16(3): 425-448.

[26] Jenkins, M., Johnson, G. Linking Managerial Cognition and Organizational Performance: A Preliminary Investigation Using Causal Maps. British Journal of Management, 1997, 8(s1): 77-90.

[27] Kiesler, S., Sproull, L. Managerial Response to Changing Environments: Perspectives on Problem Sensing from Social Cognition. Administrative Science Quarterly, 1982, 27(4): 548-570.

[28] Barr, P.S., Stimpert, J.L, Huff, A.S. Cognitive change, strategic action, and organizational renewal. Strategic Management Journal, 1992, 13(s1):15-36.

[29] Miller D, Chen M J. Sources and Consequences of Competitive Inertia: A Study of the US Airline Industry. Administrative Science Quarterly, 1994, 39(1):1-23.

[30] Cho, T. S. \& Hambrick, D. C. 2006. Attention as the Mediator Between Top Management Team Characteristics and Strategic Change: The Case of Airline Deregulation. Organization Science, 17(4): 453-469.

[31] Kaplan, S. Cognition, Capabilities, and Incentives: Assessing Firm Response to the Fiber-Optic Revolution. Academy of Management Journal, 2008, 51(4): 672-695.

[32] Eggers, J.P., Kaplan, S. Cognition and Renewal: Comparing CEO and Organizational Effects on Incumbent Adaptation to Technical Change. Organization Science, 2009, 20(2): 461-477.

[33] Nadkarni, S., Barr, P. S. Environmental context, managerial cognition, and strategic action: an integrated view. Strategic Management Journal, 2008, 29(13): 1395-1427.

[34] McCarthy, I.P., Lawrence, T.B., Wixted, B. and Gordon, B.R. A Multidimensional Conceptualization of Environmental Velocity. The Academy of Management Review, 2010, 35(4): 604-626.

[35] Plambeck, N., Weber, K. CEO Ambivalence and Responses to Strategic Issues. Organization Science, 2009, 20(6):993-1010.

[36] Dutton, J.E., Jackson, S.E. Categorizing Strategic Issues: Links to Organizational Action. The Academy of Management Review, 1987, 12(1): 76-90. 
[37] Katila, R. Chen, E.L. Effects of Search Timing on Innovation: The Value of Not Being in Sync with Rivals. Administrative Science Quarterly, 2008, 53: 593-625.

[38] Gavetti, G., Levinthal, D. Looking forward and looking backward: Cognitive and experiential search. Administrative Science Quarterly, 2000, 45: 113-137.

[39] Mosakowski, E., Earley, P.C. A selective review of time assumptions in strategy research. Academy of Management Review, 2000, 25(4): 796-812.

[40] D. Lovallo, T.C. Powell, C.R. Fox, and D.J.Teece. Strategic Management Journal Special Issue Call For Papers. Psychological Foundations of Strategic Management. Journal of Strategic Management, 2008, 1-3.

[41] Duriau, V.J., Reger, R.K., Pfarrer, M.D. A Content Analysis of the Content Analysis Literature in Organization Studies: Research Themes, Data Sources, and Methodological Refinements. Organizational Research Methods, 2007, 10(1): 5-34.

[42] Senior, C., Lee, N., and Butler, M. Perspective-Organizational Cognitive Neuroscience. Organization Science, 2011, 22(3): 804-815.

[43] Deborah G. Ancona, Paul S. Goodman, Barbara S. Lawrence, Michael L. Tushman. Time: A New Research Lens. Academy of Management Review, 2001, 26(4): 645663.

[44] Eisenhardt, K.M. Has strategy changed. MIT Sloan Management Review, 2002, 88-91.

[45] Ocasio, W. Towards an attention-based theory of the firm. Strategic Management Journal, 1997, 18 (S1): 187-206. 


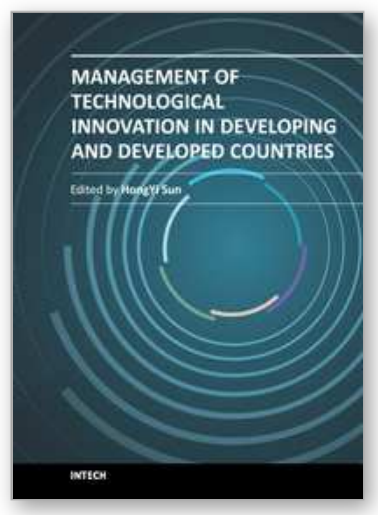

\section{Management of Technological Innovation in Developing and Developed Countries}

Edited by Dr. HongYi Sun

ISBN 978-953-51-0365-3

Hard cover, 312 pages

Publisher InTech

Published online 21, March, 2012

Published in print edition March, 2012

It is widely accepted that technology is one of the forces driving economic growth. Although more and more new technologies have emerged, various evidence shows that their performances were not as high as expected. In both academia and practice, there are still many questions about what technologies to adopt and how to manage these technologies. The 15 articles in this book aim to look into these questions. There are quite many features in this book. Firstly, the articles are from both developed countries and developing countries in Asia, Africa and South and Middle America. Secondly, the articles cover a wide range of industries including telecommunication, sanitation, healthcare, entertainment, education, manufacturing, and financial. Thirdly, the analytical approaches are multi-disciplinary, ranging from mathematical, economic, analytical, empirical and strategic. Finally, the articles study both public and private organizations, including the service industry, manufacturing industry, and governmental organizations. Given its wide coverage and multidisciplines, the book may be useful for both academic research and practical management.

\section{How to reference}

In order to correctly reference this scholarly work, feel free to copy and paste the following:

Xuanwei Cao (2012). Incorporating Technological Innovation and Environmental Strategy: An Integrated View of Cognition and Action, Management of Technological Innovation in Developing and Developed Countries, Dr. HongYi Sun (Ed.), ISBN: 978-953-51-0365-3, InTech, Available from:

http://www.intechopen.com/books/management-of-technological-innovation-in-developing-and-developedcountries/incorporating-technological-innovation-and-environmental-strategy-an-integrated-view-of-cognitionan

\section{INTECH}

open science | open minds

\section{InTech Europe}

University Campus STeP Ri

Slavka Krautzeka 83/A

51000 Rijeka, Croatia

Phone: +385 (51) 770447

Fax: +385 (51) 686166

www.intechopen.com

\section{InTech China}

Unit 405, Office Block, Hotel Equatorial Shanghai

No.65, Yan An Road (West), Shanghai, 200040, China

中国上海市延安西路65号上海国际贵都大饭店办公楼 405 单元

Phone: +86-21-62489820

Fax: +86-21-62489821 
(C) 2012 The Author(s). Licensee IntechOpen. This is an open access article distributed under the terms of the Creative Commons Attribution 3.0 License, which permits unrestricted use, distribution, and reproduction in any medium, provided the original work is properly cited. 